\title{
The Role of L- and T-Type Calcium Channels in Local and Remote Calcium Responses in Rat Mesenteric Terminal Arterioles
}

\author{
Thomas Hartig Braunstein $^{a}$ Ryuji Inoue ${ }^{b}$ Leanne Cribbs ${ }^{d}$ Masahiro Oike ${ }^{c}$ \\ Yushi Ito $^{c}$ Niels-Henrik Holstein-Rathlou ${ }^{a}$ Lars Jørn Jensen ${ }^{a}$ c \\ ${ }^{a}$ Division of Renal and Vascular Research, Department of Biomedical Sciences, Panum Institute, University of \\ Copenhagen, Copenhagen, Denmark; ${ }^{b}$ Department of Physiology, Fukuoka University School of Medicine, and \\ 'Department of Pharmacology, Graduate School of Medical Sciences, Kyushu University, Fukuoka, Japan; \\ ${ }^{\mathrm{d}}$ Loyola University Medical Center, Maywood, III., USA
}

\section{Key Words}

$\mathrm{Ca}^{2+}$ channels $\cdot$ Conducted vascular responses .

Endothelium · Gap junctions · Intercellular

communication $\cdot$ Vascular smooth muscles

\begin{abstract}
Background/Aims: The roles of intercellular communication and T-type versus L-type voltage-dependent $\mathrm{Ca}^{2+}$ channels (VDCCs) in conducted vasoconstriction to local $\mathrm{KCl}$-induced depolarization were investigated in mesenteric arterioles. Methods: Ratiometric Ca ${ }^{2+}$ imaging (R) using Fura-PE3 with micro-ejection of depolarizing $\mathrm{KCl}$ solution and VDCC blockers, and immunohistochemical and RT-PCR techniques were applied to isolated rat mesenteric terminal arterioles $(n=71$ from 47 rats; intraluminal diameter: $24 \pm 1 \mu \mathrm{m}$; length: 550 $700 \mu \mathrm{m})$. Results: Local application of $\mathrm{KCl}(a t 0 \mu \mathrm{m})$ led to local $(\Delta R=0.54)$ and remote $(\Delta R=0.17$ at $500 \mu \mathrm{m})$ increases in intracellular $\mathrm{Ca}^{2+}$. Remote $\mathrm{Ca}^{2+}$ responses were inhibited by the gap junction uncouplers carbenoxolone and palmitoleic acid. Cav1.2, Cav3.1 and Cav3.2 channels were immunolocalized in vascular smooth muscle cells and Cav3.2 in adjacent endothelial cells. Local and remote $\mathrm{Ca}^{2+}$ responses were inhibited by bath application of $\mathrm{L}$ - and T-type blockers [nifedipine, NNC 55-0396 and R(-)-efonidipine]. Remote $\mathrm{Ca}^{2+}$
\end{abstract}

responses $(500 \mu \mathrm{m})$ were not affected by abolishing $\mathrm{Ca}^{2+}$ entry at an intermediate position on the arterioles (at 200-300 $\mu \mathrm{m})$ using micro-application of VDCC blockers. Conclusion: Both L- and T-type channels mediate $\mathrm{Ca}^{2+}$ entry during conducted vasoconstriction to local $\mathrm{KCl}$ in mesenteric arterioles. However, these channels do not participate in the conduction process per se.

Copyright $\odot 2008$ S. Karger AG, Basel

\section{Introduction}

A vascular conducted response is the phenomenon whereby a locally initiated vasodilatation or vasoconstriction is conducted along the arteriolar wall independently of blood flow, diffusible factors or neural activity. Conducted vasodilatation and vasoconstriction play important roles in the local coordination of blood flow within tissues in response to changes in metabolic demand [1-3], and intercellular communication via gap junctions is believed to be crucial for conduction of these responses $[4,5]$. Gap junction-forming connexins providing low-resistance electrical coupling were found to be expressed in rat mesenteric terminal arterioles [6]; however, functional evidence for the involvement of gap junc-

\section{KARGER}

Fax +41613061234 E-Mail karger@karger.ch www.karger.com
(C) 2008 S. Karger AG, Basel

$1018-1172 / 09 / 0462-0138 \$ 26.00 / 0$

Accessible online at:

www.karger.com/jvr
Dr. Lars Jørn Jensen

Division of Renal and Vascular Research, Department of Biomedical Sciences

Panum Institute (10.5)

Blegdamsvej 3, DK-2200 Copenhagen N (Denmark)

Tel. +45 353274 01, Fax +45 3532 74 18, E-Mail ljj@mfi.ku.dk 
tions in the conduction of vasoconstrictor signals in this vascular bed is still lacking. In several arteriolar preparations, local depolarization is conducted along the vascular wall and is followed by both local and conducted vasoconstriction $[7,8]$. As voltage-dependent $\mathrm{Ca}^{2+}$ entry is a central step in excitation-contraction coupling, we aimed to investigate $\mathrm{Ca}^{2+}$ signals underlying conducted vasoconstriction to local depolarization in arterioles. In rat mesenteric terminal arterioles, a role for a T-type voltage-dependent $\mathrm{Ca}^{2+}$ channel (VDCC) in $\mathrm{Ca}^{2+}$ entry and vasoconstriction has been proposed [9-11]. However, the expression and localization of T-type protein in mesenteric arterioles has not yet been demonstrated. In the present study, we examined the functional nature of conducted vasoconstriction initiated by local application of $\mathrm{KCl}$ in rat mesenteric terminal arterioles, and sought the potential role of VDCCs in this process. The main findings are that both L- and T-type channels are expressed at the protein level in mesenteric arterioles and are important for electromechanical coupling. However, they are not necessary for conduction of vasoconstriction to local $\mathrm{KCl}$ application.

\section{Materials and Methods}

\section{Animals and Preparation}

Male Sprague-Dawley rats (150-200 g; Charles River, Tokyo, Japan, or Taconic, Lille Skensved, Denmark) were sacrificed using pentobarbital sodium (Nembutal, $65 \mathrm{mg} / \mathrm{kg}$ i.p.). A mesenteric fat pad was excised along with a 5th-order mesenteric artery and its peripheral branches. The excised tissue was submerged in PSS containing $1 \%$ bovine serum albumin (low endotoxin) and placed under a stereomicroscope $(\times 30$ magnification $)$ where terminal arterioles (intraluminal diameter, ID, $10-40 \mu \mathrm{m}$; length 550-700 $\mu \mathrm{m})$ were microdissected from their parent vessel.

Isolated arterioles (fig. 1) were made to adhere to the glass bottom of a perfusion chamber (model RC-22, Warner Instrument, Hamden, Conn., USA) by Cell Tak (Becton Dickinson Labware, Bedford, Mass., USA), and herein incubated for 90-120 min (at room temperature) with PSS containing (in $\mathrm{mM}$ ): $140 \mathrm{NaCl}, 5 \mathrm{KCl}$, $1.2 \mathrm{MgCl}_{2}, 2 \mathrm{CaCl}_{2}, 10$ HEPES and 10 glucose ( $\mathrm{pH}$ 7.4); to which $5 \mu \mathrm{M}$ Fura-PE3/AM, 1\% BSA, 0.1\% DMSO, 0.02\% Pluronic F127 and $0.06 \%$ Cremophore EL had been added. After abluminal loading of Fura, the vessels were rinsed with PSS and allowed to rest for $\geq 20$ min before each experiment. In $\mathrm{Ca}^{2+}$-free PSS, $2 \mathrm{~mm}$ $\mathrm{CaCl}_{2}$ was replaced with $2 \mathrm{mM}$ EGTA. In PSS used for preconstriction of arterioles, $25 \mathrm{~mm} \mathrm{NaCl}$ was replaced mole for mole with $\mathrm{KCl}$. In experiments using low $\left[\mathrm{Na}^{+}\right], 126 \mathrm{mM} \mathrm{NaCl}$ was replaced with $126 \mathrm{mM} \mathrm{N}$-methyl-D-glucamine-Cl. The recording chamber $(\sim 0.1 \mathrm{ml}$ capacity) was mounted on the stage of an inverted epifluorescence microscope (Olympus IX70) placed on top of a vibration-free table (Newport, Irvine, Calif., USA). Solutions were added via continuous superfusion (flow rate $\sim 1 \mathrm{ml} / \mathrm{min}$ ), and excess solution was removed by suction. Experiments were per-
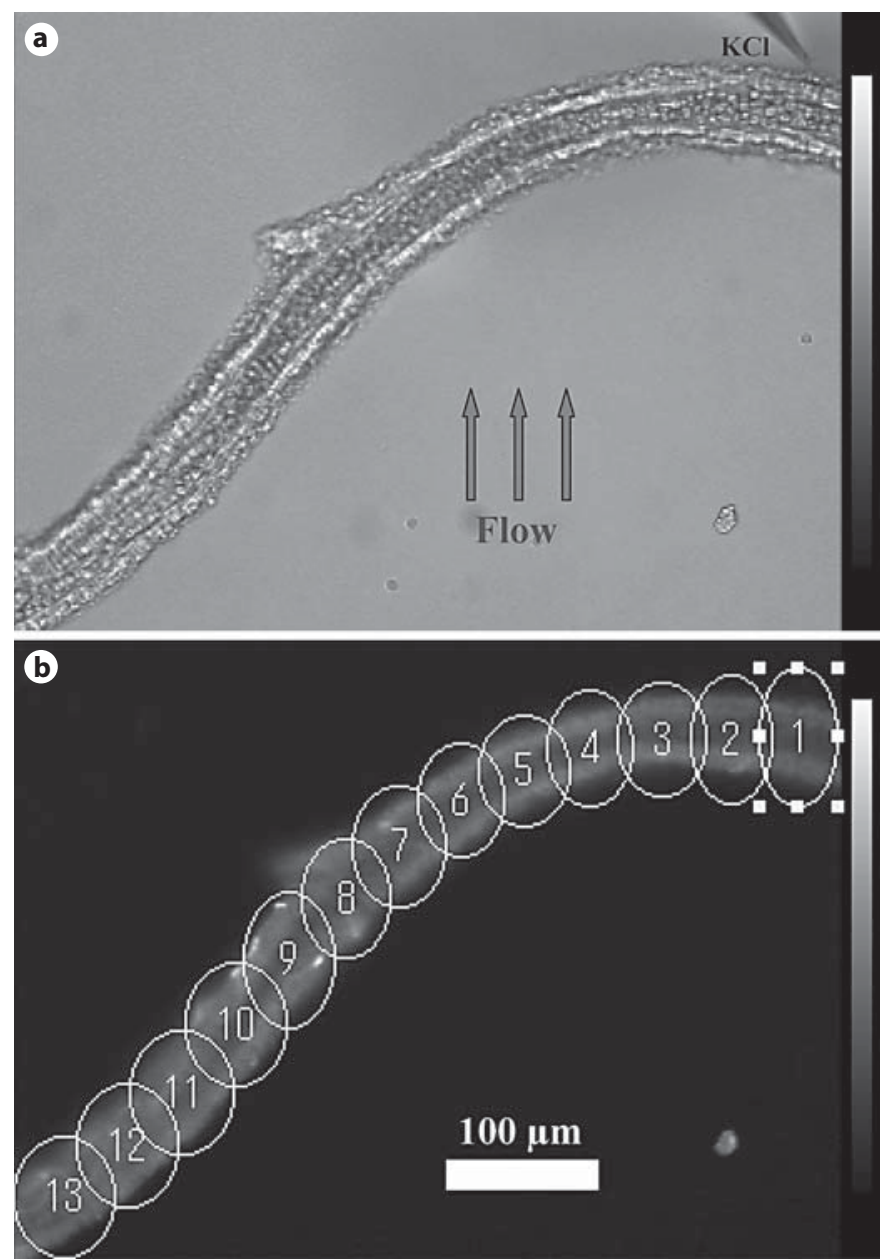

Fig. 1. a Bright-field image of isolated mesenteric terminal arteriole loaded with ratiometric $\mathrm{Ca}^{2+}$ indicator Fura-PE3 and mounted on a cover slide for measurement of $\left[\mathrm{Ca}^{2+}\right]_{\mathrm{i}}$. Pipette tip for micro-ejection of $\mathrm{KCl}$ is visible in the upper right corner. Direction of the superfusion flow is indicated by arrows. b Same arteriole shown with excitation of Fura-PE3 at $340 \mathrm{~nm}$ and with emission collected at $510 \mathrm{~nm}$. Numbered circles indicate ROIs for $\mathrm{Ca}^{2+}$ measurement.

formed at room temperature $\left(25-28^{\circ} \mathrm{C}\right)$. Rat anesthesia and euthanasia were done according to the local guidelines for animal research at Kyushu University and University of Copenhagen.

\section{Calcium Imaging and Diameter Measurements}

A $\times 20$ quartz objective (Olympus UApo/340) with numerical aperture $=0.75$ was used for $\mathrm{Ca}^{2+}$ measurements. The non-pressurized arterioles were visualized on a PC monitor using a CCD camera (Hamamatsu Hi SCA C6790, Hamamatsu City, Japan) and Aquacosmos software (Hamamatsu). Using a polychromator (Hamamatsu C7773) controlled by the software, arterioles were excited with light of alternating wavelengths (340 vs. $380 \mathrm{~nm}$; 100 $\mathrm{ms}$ exposure for each wavelength; images acquired every $2 \mathrm{~s}$ ). Regions of interest (ROIs, approximately $50 \times 50 \mu \mathrm{m}$ ) for the mea- 
surement of intracellular calcium concentration $\left(\left[\mathrm{Ca}^{2+}\right]_{\mathrm{i}}\right)$ were placed next to each other covering the entire length of an arteriole (fig. 1b). The recorded 340- and 380-nm images and fluorescence intensities were stored on a PC hard disk. The field of view was $400 \times 535 \mu \mathrm{m}$, and by arranging arterioles diagonally within the camera field, $\left[\mathrm{Ca}^{2+}\right]_{\mathrm{i}}$ could be measured simultaneously along $\sim 600 \mu \mathrm{m}$ of an arteriole (fig. 1). Before data analysis, the length and diameter of an arteriole were measured using ImageJ software (version 1.34i; Wayne Rasband, National Institutes of Health, Bethesda, Md., USA) using stored 340-nm fluorescent and brightfield images. Then each ROI was assigned a distance $(0-500 \mu \mathrm{m})$ from the site of local stimulation also using ImageJ. The Fura ratio $\left(\mathrm{R}=\mathrm{F}_{340} / \mathrm{F}_{380}\right)$ for each $\mathrm{ROI}$ was calculated after a constant background value had been subtracted from the intensity measured at each wavelength. Results presented in the text and illustrations are either $\mathrm{R}$ values or $\Delta \mathrm{R}$ values (peak $\mathrm{R}$ - baseline $\mathrm{R}$ ).

Images were focused inside the media layer, which could be visualized as brightly fluorescent bands of vascular smooth muscle cells (VSMCs) oriented perpendicularly to the length axis of the vessel, in order to record $\mathrm{Ca}^{2+}$ responses from the VSMCs only. In a subset of experiments, ID and $\mathrm{R}$ were tracked simultaneously during local application of $\mathrm{KCl}$ (fig. 2a). By adjusting the focal plane through the mid point of the vessel such that the lumen was clearly visible, ID was measured on each successive 340 $\mathrm{nm}$ image. Subsequently, $\mathrm{R}$ and ID were plotted for both local $(0 \mu \mathrm{m})$ and remote sites $(500 \mu \mathrm{m})$.

All estimates of $\mathrm{Ca}^{2+}$ concentrations were based on in vitro calibration of the $\mathrm{Ca}^{2+}$ imaging system. Calibration was performed as previously described [10] using Fura-PE3 $\mathrm{K}^{+}$salt and a $\mathrm{K}_{\mathrm{d}}$ of $290 \mathrm{nM}$ for Fura-PE3 in the presence of $\mathrm{Mg}^{2+}$ [12]. Fluorescence of bound versus unbound dye at 340 and $380 \mathrm{~nm}$ was determined using commercial calibration buffers (Invitrogen-Molecular Probes, Eugene, Oreg., USA) with low versus high $\left[\mathrm{Ca}^{2+}\right]$ in the presence of EGTA, $\mathrm{Mg}^{2+}$, and at constant ionic strength ( $\left.\mathrm{pH} 7.2\right)$ and temperature.

\section{Localized Application of KCl and Drugs}

Local depolarization was imposed using pressure micro-ejection of $\mathrm{KCl}(155 \mathrm{mM}, 0.1 \%$ phenol red, $10 \mathrm{mM}$ HEPES, pH 7.4). In brief, the tip of a micropipette (3-5 $\mu \mathrm{m}$ ) pulled from 1.0-mm glass capillaries (Narishige, Tokyo, Japan) using a horizontal pipette puller (model P-97, Sutter Instrument, Novato, Calif., USA) was positioned $<10 \mu \mathrm{m}$ from an arteriole. A short puff of $\mathrm{KCl}(1,500$ $\mathrm{ms}$ ) was given (at $30 \mathrm{psi}$ ) onto the arteriole using a Narishige IM 300 programmable microinjector. The pipette tip was positioned so that the ejected $\mathrm{KCl}$ was carried away perpendicularly to the arteriolar length axis. Before each experiment, it was visually confirmed that upon micro-ejection a 'cloud' of $\mathrm{KCl} /$ phenol red briefly covered a short segment $(<100 \mu \mathrm{m})$ of an arteriole before being spread in the direction of the flow. While monitoring $\left[\mathrm{Ca}^{2+}\right]_{\mathrm{i}}, \mathrm{KCl}$ was ejected three times with 4 -min intervals. Then a drug (inhibitor) was applied via superfusion for 3-10 min before repeating three $\mathrm{KCl}$ stimulations during exposure to the drug. In most experiments, the drug was then washed out for $10 \mathrm{~min}$ and the stimulation was repeated two or three times to assess reversibility.

In initial control experiments, ejection of $\mathrm{KCl}$ did not elicit a $\mathrm{Ca}^{2+}$ response when the micropipette tip was positioned $50-100$ $\mu \mathrm{m}$ above an arteriole, whereas when it was lowered onto the arteriole (as shown in fig. 1a) local and remote $\mathrm{Ca}^{2+}$ responses were readily observed at positions spatially separated by $500 \mu \mathrm{m}(\mathrm{n}=$ 2). In four arterioles, a small cut or crush was made using sharpened forceps at an intermediate position 200-300 $\mu \mathrm{m}$ distant to the micropipette tip. Prior to making a cut, local stimulation elicited a robust remote $(>500 \mu \mathrm{m}) \mathrm{Ca}^{2+}$ response. After making the cut, local stimulation (at either end of the arteriole) resulted in remote $\mathrm{Ca}^{2+}$ responses up to the point of the lesion, but remote $\mathrm{Ca}^{2+}$ responses were never observed on the opposite side of the cut.

In some experiments, drugs were delivered only to a narrow region of an arteriole. This was done by applying a gentle pressure head $(10-100 \mathrm{~mm} \mathrm{Hg})$ to a patch pipette $(4-5 \mathrm{M} \Omega)$ pulled from $1.5-\mathrm{mm}$ glass capillaries (Narishige). Again, strictly localized perifusion of a drug (dissolved in PSS $+0.1 \%$ phenol red, $\mathrm{pH} 7.4$ ) was visually confirmed before each experiment. Micropipettes were secured with Narishige Hi-6 $(1.5 \mathrm{~mm})$ or Hi-7 $(1.0 \mathrm{~mm})$ injection holders connected to the pressure source with hard polyethylene tubing, and positioned using Narishige hydraulic micromanipulators.

\section{Reverse Transcription Polymerase Chain Reaction}

Isolation of total RNA was performed using RNAlater RNA stabilization reagent and the RNeasy micro kit (Qiagen, Hilden, Germany). In brief, 67 mesenteric terminal arterioles from 5 rats were microdissected and quickly submerged in RNAlater storage solution until dissection was finished. Arterioles were then submerged in $350 \mu \mathrm{l}$ of lysis buffer containing guanidine-isothiocyanate and $\beta$-mercaptoethanol, and homogenized by repeated aspiration using a small-bore glass pipette. A total of $0.36 \mu \mathrm{g}$ of RNA was recovered following the manufacturer's instructions. Reverse transcription (RT) polymerase chain reaction (PCR) was performed twice (on pooled RNA from 2 vs. 3 rats) using a one-step RT-PCR kit (Qiagen). In brief, template RNA (in an amount corresponding to $3 \mathrm{~mm}$ of arteriole) and primer pairs $(0.6 \mu \mathrm{M})$ were mixed with RT-PCR buffer, dNTPs, reverse transcriptase and HotStarTaq DNA polymerase in a PCR tube at $4^{\circ} \mathrm{C}$. RT-PCR was

Fig. 2. a Simultaneous measurement of local $(0 \mu \mathrm{m})$ and remote $(500 \mu \mathrm{m}) \mathrm{Ca}^{2+}$ responses $\left(\mathrm{R}=\mathrm{F}_{340} / \mathrm{F}_{380}\right)$ and local and remote vasoconstriction $(\mathrm{n}=5 ; \mathrm{N}=5)$. Note that the maximal constriction could be detected $2 \mathrm{~s}$ after the peak of the $\mathrm{Ca}^{2+}$ response at both locations (the image sampling frequency precluded higher time resolution of this delay). b Global mean $\mathrm{Ca}^{2+}$ responses $(\Delta \mathrm{R}=$ peak R - baseline R) as a function of the distance to the site of local $\mathrm{KCl}$ application in terminal arterioles $(\mathrm{n}=60 ; \mathrm{N}=42 ; \mathrm{ID}=25$ $\pm 1 \mu \mathrm{m}$ ). The fitted line is a least-square regression analysis using first-order mono-exponential decay equation $Y=Y_{0}+A e^{-X / L}$ in which $X$ is conducted distance, $L$ is the empirical length constant, $Y_{0}$ is an asymptotic value and $A$ is a constant. The values of constants obtained by fitting were: $Y_{0}=0.14 ; A=0.42 ; L=161 \mu \mathrm{m}$ $\left(\mathrm{r}^{2}=0.997\right)$. When $\mathrm{Ca}^{2+}$ was removed from the superfusate, the baseline R decreased from $1.37 \pm 0.07$ to $1.19 \pm 0.03(n=3 ; N=$ 3 ) and there were no detectable increases in $\mathrm{R}$ upon local $\mathrm{KCl}$ application. c At high rate of image acquisition $(5 \mathrm{~Hz})$, there was no detectable delay in the initiation or peak of $\mathrm{Ca}^{2+}$ increase to local $\mathrm{KCl}$ application. For the purpose of illustration, $\mathrm{R}$ was normalized with the value at $0 \mathrm{~s}\left(\mathrm{R}_{0}\right)$. 


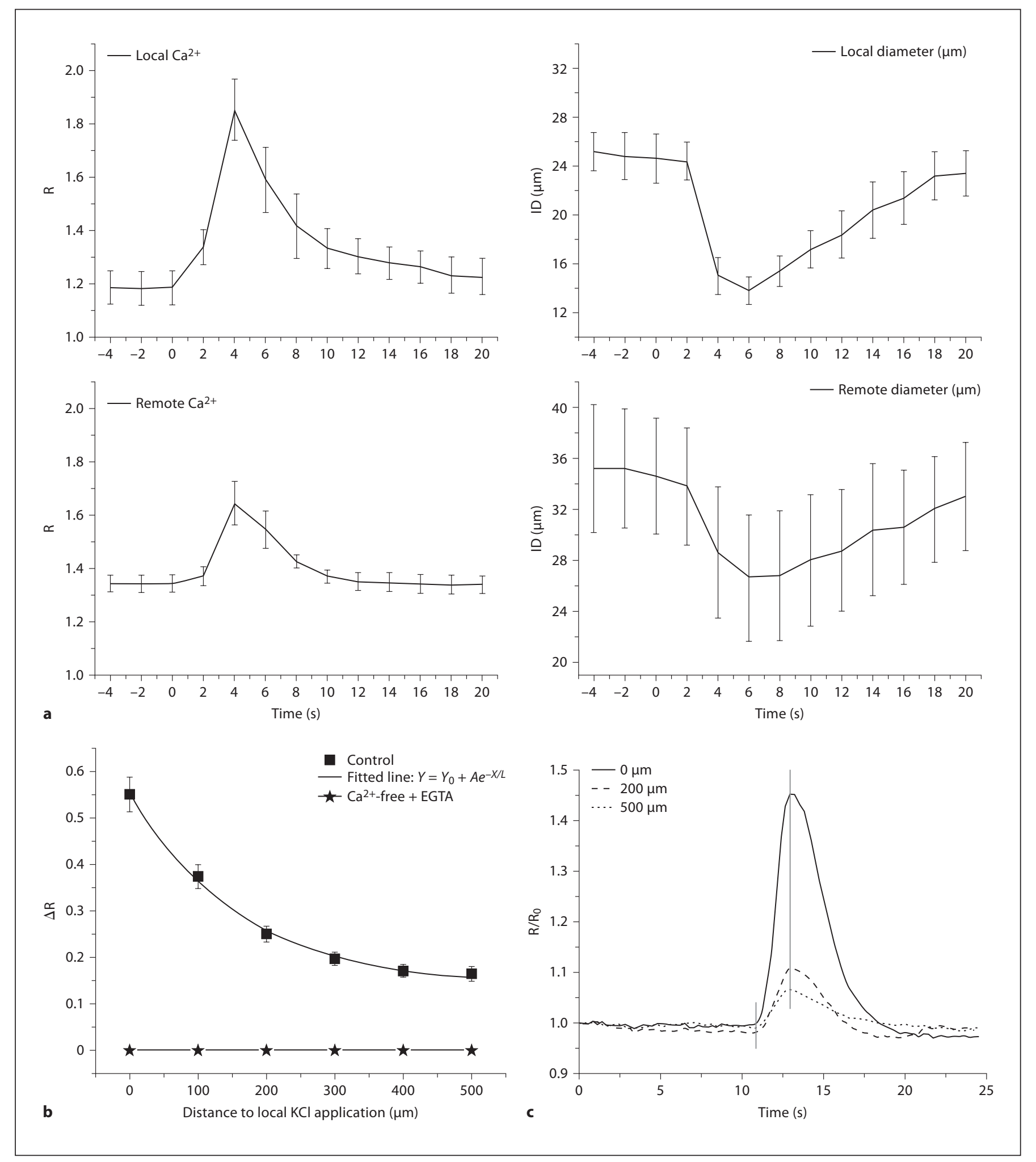


performed sequentially using the following program: RT at $50^{\circ} \mathrm{C}$ for $30 \mathrm{~min}$ followed by 33 cycles at $94^{\circ} \mathrm{C}$ for $1 \mathrm{~min}, 55^{\circ} \mathrm{C}$ for $1 \mathrm{~min}$ and $72^{\circ} \mathrm{C}$ for $1 \mathrm{~min}$.

The following primer pairs were used: $\beta$-actin (GenBank accession No. NM031144), left primer: 5'-AGCCATGTACGTAGCCATCC-3', right primer: 5'-CTCTCAGCTGTGGTGGTGAA-3' (product size 228 bp); Cav1.2 (Cagna1c, accession No. NM012517), left primer: 5'-CAGCAGGTCCTATGTCAGCA-3', right primer: 5'-CCGACAGCAGTGAATGAAGA-3' (product size 157 bp); $\mathrm{Ca}_{\mathrm{V}} 1.3$ (Cacnald, accession No. NM017298), left primer: 5'AAGGCTAAAGCACGTGGAGA-3', right primer: 5'-CACCAGAGACTTCCACAGCA-3' (product size 239 bp); Cav3.1 (Cagnalg, accession No. AF027984), left primer: 5'-CATTTGCTGTGCCTTCTTCA-3', right primer: 5'-GCCCAGGTTGTCAAAGTTGT-3' (product size 169 bp); Cav3.2 (Cagnalh, accession No. AF290213), left primer: 5'-ATCCTGGTCACTCTGCTGCT-3', right primer: 5'-ACCCTCCTCCGTCTGGTAGT-3' (product size $201 \mathrm{bp}$ ), and $\mathrm{Ca}_{\mathrm{v}} 3.3$ (Cagnali, accession No. AF086827), left primer: 5'-ACAACCCCTGGATGCTACTG-3', right primer: 5'-GCATAGTAGGGCAGCCTCTG-3' (product size 205 bp).

\section{Immunofluorescence Confocal Laser Scanning Microscopy}

Mesenteric arterioles were excised as described above and immediately fixed in $2 \%$ paraformaldehyde dissolved in phosphatebuffered saline (PBS) for $15 \mathrm{~min}$, followed by submersion in 50 $\mathrm{mM} \mathrm{NH}_{4} \mathrm{Cl}$ for $20 \mathrm{~min}$ to stop the fixation process. After rinsing with PBS, arterioles were mounted on metal stubs using TissueTek (Sakura Finetek Europe, Zoeterwoude, The Netherlands) and snap-frozen in liquid nitrogen. Sections $(12 \mu \mathrm{m})$ were cut on a Leica CM3050S cryostat (Leica Microsystems, Wetzlar, Germany) and mounted on Metzler microscope slides.

Tissue sections were permeabilized in $0.2 \%$ Triton X-100 in PBS with $1 \%$ goat serum for 15 min and blocked in PBS/1\% goat serum. All incubations with antibody were carried out in the presence of $0.1 \%$ goat serum. Sections were incubated overnight (at $4^{\circ} \mathrm{C}$ ) with primary antibodies to the following VDCC $\alpha_{1}$-subunits: $\mathrm{Ca}_{V} 1.2$ (1:25-1:50; Sigma-Aldrich; antigenic peptide from Alomone Labs, Jerusalem, Israel); $\mathrm{Ca}_{\mathrm{V}} 3.1$ (1:300-1:500; [13]), or $\mathrm{Ca}_{\mathrm{v}} 3.2$ (1:300; Alomone Labs). An antigen retrieval technique previously adapted for immunocytochemistry [14], which consisted of treatment with $1 \%$ SDS in distilled water $(2 \mathrm{~min})$, was essential for obtaining $\mathrm{Ca}_{\mathrm{V}} 1.2$-specific labeling in rat mesenteric arterioles. Peptide preincubation controls (1:1 w/w mixture; 30 min at room temperature) were included for both the Cav 1.2 and $\mathrm{Ca}_{\mathrm{v}} 3.2$ antibodies using their short epitopic peptides. After the primary incubation, sections were washed and incubated with goat anti-rabbit secondary antibody conjugated with Alexa-488 (1:800; Molecular Probes) and rhodamine-phalloidin (Molecular Probes) at room temperature for $45 \mathrm{~min}$. After several washing steps, sections were mounted in ProLong Gold mounting medium (Molecular Probes) and imaged using a Leica TCS SP2 confocal laser scanning microscope. The same laser intensity and recording settings were used when comparing staining patterns or intensity between different sections.

\section{Chemicals}

All chemicals were purchased from Sigma-Aldrich (St. Louis, Mo., USA), with the exception of tetrodotoxin (Wako Pure Chemical Industries, Osaka, Japan) and R(-)-efonidipine (Nissan
Chemical Industries, Tokyo, Japan). Stock solutions of nifedipine, $\mathrm{R}(-)$-efonidipine and palmitoleic acid (cis-9-hexadecanoic acid) were prepared with DMSO. Stock solutions of other drugs were prepared with Millipore $\mathrm{H}_{2} \mathrm{O}$ and stored at $-20^{\circ} \mathrm{C}$ for use within 1 month.

\section{Data Analysis and Presentation}

Data are presented as raw data or means \pm SE $(n=$ number of arterioles; $\mathrm{N}=$ number of rats) for Fura ratio and diameter measurements. Local and remote responses were evaluated as the difference between baseline and peak $\mathrm{R}(\Delta \mathrm{R})$. Statistical analysis was done using SigmaStat 3.0, and statistical significance $(\mathrm{p}<0.05)$ was determined by either paired Student's t test or Wilcoxon's rank sum test. Non-linear curve fitting was performed with Origin 6.1 using a least-square fit of the single exponential function shown in figure $2 b$.

\section{Results}

\section{Initial Characterization of Remote $\mathrm{Ca}^{2+}$ Responses}

In 71 arterioles from 47 rats with ID $=24.1 \pm 1.0 \mu \mathrm{m}$, the overall local response at the site of local $\mathrm{KCl}$ microejection $(0 \mu \mathrm{m})$ was an increase in $\mathrm{R}$ from $1.25 \pm 0.02$ to $1.79 \pm 0.04$ (corresponding to an increase in $\left[\mathrm{Ca}^{2+}\right]_{\mathrm{i}}$ from 88 to $283 \mathrm{nM})$. The simultaneously measured $\mathrm{Ca}^{2+}$ response at a remote site $(500 \mu \mathrm{m})$ was an increase in $\mathrm{R}$ from $1.32 \pm 0.02$ to $1.49 \pm 0.02$ (increase in $\left[\mathrm{Ca}^{2+}\right]_{\mathrm{i}}$ from 110 to $167 \mathrm{nM})$. Simultaneous tracking of ID and $\left[\mathrm{Ca}^{2+}\right]_{\mathrm{i}}$ (R) was performed in 5 arterioles from 5 rats during local $\mathrm{KCl}$ stimulation (fig. 2a). We observed a local increase in $\left[\mathrm{Ca}^{2+}\right]$ followed by a local constriction, and, at a distance of $500 \mu \mathrm{m}$ to the site of stimulation, a smaller remote $\mathrm{Ca}^{2+}$ response was also followed by vasoconstriction. At both locations, peak constriction could be detected $2 \mathrm{~s}$ after peak $\mathrm{R}$.

In figure $2 \mathrm{~b}$, mean $\Delta \mathrm{R}$ values are plotted versus distance from the local site of $\mathrm{KCl}$ application $(0-500 \mu \mathrm{m})$. The data points exhibit a monotonic decay suggesting that the remote $\mathrm{Ca}^{2+}$ responses decayed exponentially with distance. Indeed, the responses $(0-500 \mu \mathrm{m})$ could be approximated by a first-order exponential equation $Y=Y_{0}+A e^{-X / L}$, in which $X$ is distance, $Y$ is $\Delta \mathrm{R}, Y_{0}$ is an asymptote, and $A$ and $L$ are constants (see legend of fig. $2 \mathrm{~b})$. When extracellular $\mathrm{Ca}^{2+}$ was replaced by EGTA, all $\mathrm{Ca}^{2+}$ responses were abolished, and the $\mathrm{Ca}^{2+}$ responses returned to the control level when extracellular $\mathrm{Ca}^{2+}$ was reintroduced via the superfusate.

Even with the fastest acquisition rate attainable $(5 \mathrm{~Hz})$ we could not detect any time lag in activation or peak of $\mathrm{Ca}^{2+}$ responses obtained at 0,200 or $500 \mu \mathrm{m}$ (fig. $2 \mathrm{c}$ ). The estimated $90 \%$ rise time $\left(\tau_{90}\right)$ from the onset of the 
Table 1. Lack of effect of tetrodotoxin (TTX), low $\left[\mathrm{Na}^{+}\right]$or vehicle (DMSO) on local and remote $\mathrm{Ca}^{2+}$ responses

\begin{tabular}{|c|c|c|c|c|c|c|}
\hline \multirow[t]{2}{*}{$\Delta \mathrm{R} \pm \mathrm{SE}$} & \multicolumn{6}{|l|}{ Distance } \\
\hline & $0 \mu \mathrm{m}$ & $100 \mu \mathrm{m}$ & $200 \mu \mathrm{m}$ & $300 \mu \mathrm{m}$ & $400 \mu \mathrm{m}$ & $500 \mu \mathrm{m}$ \\
\hline Control $(\mathrm{n}=5 ; \mathrm{N}=4)$ & $0.53 \pm 0.09$ & $0.36 \pm 0.07$ & $0.25 \pm 0.06$ & $0.20 \pm 0.05$ & $0.17 \pm 0.04$ & $0.18 \pm 0.06$ \\
\hline TTX $(1-5 \mu \mathrm{M})$ & $0.51 \pm 0.07$ & $0.37 \pm 0.07$ & $0.28 \pm 0.07$ & $0.24 \pm 0.05$ & $0.21 \pm 0.05$ & $0.23 \pm 0.07$ \\
\hline $\mathrm{ID}, \mu \mathrm{m}$ & $22 \pm 4$ & & & & & \\
\hline Control $(\mathrm{n}=4 ; \mathrm{N}=2)$ & $0.67 \pm 0.12$ & $0.57 \pm 0.18$ & $0.37 \pm 0.11$ & $0.30 \pm 0.06$ & $0.25 \pm 0.04$ & $0.24 \pm 0.07$ \\
\hline Low $\left[\mathrm{Na}^{+}\right](14 \mathrm{mM})$ & $0.74 \pm 0.11$ & $0.59 \pm 0.10$ & $0.39 \pm 0.09$ & $0.33 \pm 0.08$ & $0.31 \pm 0.10$ & $0.17 \pm 0.02$ \\
\hline $\mathrm{ID}, \mu \mathrm{m}$ & $23 \pm 3$ & & & & & \\
\hline Control $(\mathrm{n}=5 ; \mathrm{N}=4)$ & $0.31 \pm 0.06$ & $0.20 \pm 0.05$ & $0.16 \pm 0.03$ & $0.14 \pm 0.03$ & $0.13 \pm 0.03$ & $0.11 \pm 0.03$ \\
\hline DMSO (0.1\%) & $0.33 \pm 0.07$ & $0.23 \pm 0.07$ & $0.17 \pm 0.04$ & $0.16 \pm 0.04$ & $0.14 \pm 0.03$ & $0.11 \pm 0.03$ \\
\hline $\mathrm{ID}, \mu \mathrm{m}$ & $20 \pm 3$ & & & & & \\
\hline
\end{tabular}

local $\mathrm{Ca}^{2+}$ response to the peak of the local or the remote $\mathrm{Ca}^{2+}$ responses were $1.82 \pm 0.21 \mathrm{~s}$ at $0 \mu \mathrm{m}, 1.83 \pm 0.24 \mathrm{~s}$ at $200 \mu \mathrm{m}$ and $1.90 \pm 0.22 \mathrm{~s}$ at $500 \mu \mathrm{m}(\mathrm{n}=4 ; \mathrm{N}=2)$. As there was no difference between remote responses at 200 versus $500 \mu \mathrm{m}$, the conduction velocity was faster than $300 \mu \mathrm{m}$ per $200 \mathrm{~ms}$ (= interval between images), i.e. $>1.5 \mathrm{~mm} / \mathrm{s}$.

\section{Effects of Blockade of $\mathrm{Na}^{+}$Channels}

A velocity of this magnitude suggests electrical conduction along the vascular wall, and to investigate this possibility we tested the effects of voltage-gated $\mathrm{Na}^{+}$ channel inhibition. In 5 arterioles tetrodotoxin at a concentration sufficient to inhibit neuronal $\mathrm{Na}^{+}$channels (1-5 $\mu \mathrm{M})$ did not affect local or remote responses (table 1). In addition, we tested the effect of substituting $90 \%$ of $\mathrm{Na}^{+}$ions in the superfusate with $\mathrm{N}$-methyl-D-glucamine $(126 \mathrm{mM})$. There were no effects on local or remote $\mathrm{Ca}^{2+}$ responses in the presence of low $\left[\mathrm{Na}^{+}\right]$PSS (table 1).

\section{Effects of Gap Junction Uncouplers}

Next, we tested whether gap junctions mediate the remote response to local $\mathrm{KCl}$. Palmitoleic acid is a $16 \mathrm{C}$ fatty acid capable of blocking gap junctional intercellular communication in blood vessels $[15,16]$. Palmitoleic acid $(50 \mu \mathrm{M})$ irreversibly abolished remote $\mathrm{Ca}^{2+}$ responses to local $\mathrm{KCl}$ with no effect on the baseline $\mathrm{R}$ or local $\mathrm{Ca}^{2+}$ responses (fig. 3a). Carbenoxolone is a water-soluble molecule derived from $\beta$-glycyrrhetinic acid, and it is capable of blocking gap junctional intercellular communication in blood vessels $[15,17]$. When applied at $30 \mu \mathrm{M}(\mathrm{n}=6$; $\mathrm{p}=0.066$; data not shown) or $100 \mu \mathrm{M}$ (fig. 3b), carben- oxolone reversibly reduced the remote $\mathrm{Ca}^{2+}$ responses in a concentration-dependent manner with no effect on the baseline $\mathrm{R}$ or local $\mathrm{Ca}^{2+}$ responses. In addition, we tested the effect of the highest concentration of vehicle DMSO $(0.1 \%)$ used. There were no effects of DMSO on the baseline $\mathrm{R}$ (not shown) or the local and remote $\mathrm{Ca}^{2+}$ responses to local $\mathrm{KCl}$ application (table 1 ).

\section{Expression of VDCC $\alpha_{1}$-Subunits in Mesenteric \\ Terminal Arterioles}

RT-PCR amplification with subtype-specific primers successfully detected the messages of $\mathrm{Ca}_{\mathrm{V}} 1.2, \mathrm{Ca}_{\mathrm{V}} 3.1$ and $\mathrm{Ca}_{\mathrm{V}} 3.2$ channels (fig. 4). Marginal expression of $\mathrm{Ca}_{\mathrm{V}} 1.3$ subtype was also suggested by a faint band; however, this might reflect contamination from perivascular nerve endings. In contrast, no evidence was obtained for the expression of the brain T-type isoform $\mathrm{Ca}_{\mathrm{v}} 3$ 3.3. These data suggest that both L- and T-type channels are expressed in mesenteric terminal arterioles.

We next attempted to verify the expression of the VDCC subtypes described above at the protein level, and to characterize their localization by immunofluorescence laser confocal scanning microscopy. Our initial experiments failed to reveal consistent labeling of $\mathrm{Ca}_{\mathrm{V}} 1.2$ in mesenteric terminal arterioles. However, with the use of an epitope-unmasking technique consisting of short SDS treatment of tissue sections [14], we consistently obtained immunostaining of $\mathrm{Ca}_{\mathrm{V}} 1.2$ protein in VSMC of mesenteric arterioles $(\mathrm{n}=3 ; \mathrm{N}=2$; fig. $5 \mathrm{a})$. This was not due to some nonspecific action of the antibodies used after SDS treatment, since the staining was blocked by preincubation with epitopic peptide ( $\mathrm{N}=2$; data not shown). In addition, positive staining was also observed without SDS 


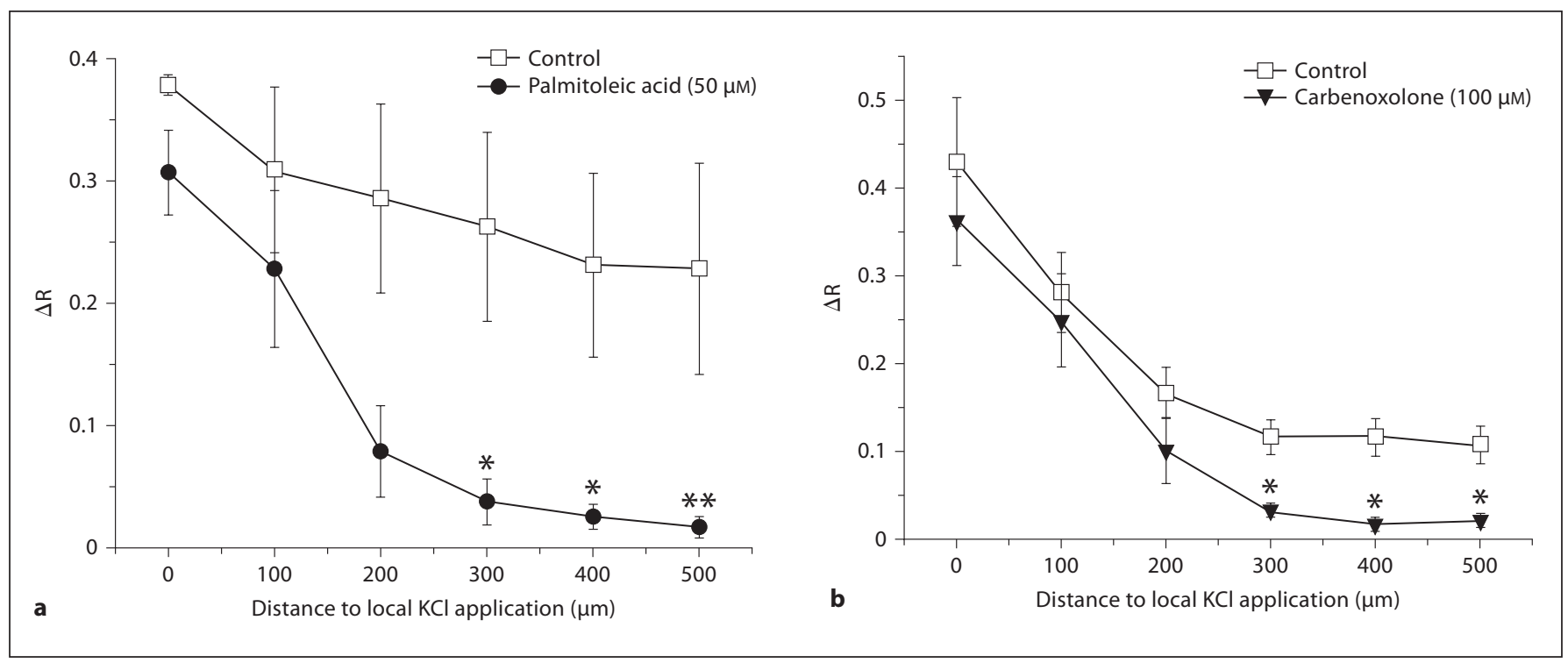

Fig. 3. a Summary of results obtained with the gap junction uncoupler palmitoleic acid $\left({ }^{*} \mathrm{p}<0.05 ;{ }^{* *} \mathrm{p}<0.01\right.$; $\mathrm{n}=5 ; \mathrm{N}=4 ; \mathrm{ID}=26 \pm 3 \mu \mathrm{m})$. $\mathbf{b}$ Summary of results obtained with the gap junction uncoupler carbenoxolone $\left({ }^{*} \mathrm{p}<0.05 ; \mathrm{n}=8 ; \mathrm{N}=4 ; \mathrm{ID}=22 \pm 3 \mu \mathrm{m}\right)$.

treatment in VSMC from renal afferent arterioles $(\mathrm{N}=2$; fig. 5b) and in cardiac myocytes $(\mathrm{N}=3$; fig. 5 c).

Staining for the $\mathrm{Ca}_{\mathrm{v}} 3.1 \alpha_{1}$-subunit was observed in the media of mesenteric terminal arterioles $(\mathrm{n}=18 ; \mathrm{N}=3$; fig. 6a, c). The Cav3.1-specific staining was intense and clearly confined to the single layer of VSMC (fig. 6c), but not found in endothelial cells (ECs): observe lack of staining around endothelial nuclei (fig. 6b). The same staining pattern was observed in small mesenteric arteries $(n=6$; $\mathrm{N}=2$; fig. 6e, f).

Figure 7 depicts the results $(n=8 ; N=2)$ for the $\mathrm{Ca}_{V} 3.2$ $\alpha_{1}$-subunit. While intense staining was observed in EC, more diffuse cytoplasmic staining was detected in VSMC (fig. 7). The staining was eliminated by preincubation of the antibody with its epitopic peptide or with secondary antibody alone ( $\mathrm{N}=2$; data not shown).

\section{Effects of Calcium Channel Blockers}

To quantify the contribution of T-type VDCCs to local and remote $\mathrm{Ca}^{2+}$ responses, we tested the effects of a classical T-type blocker mibefradil [18], and the newly developed T-type-specific blockers NNC 55-0396 [19] and (R-)-efonidipine [20, 21]. As shown in table 2, mibefradil inhibited both local and remote $\mathrm{Ca}^{2+}$ responses in a concentration-dependent manner. These effects were partially reversible and use dependent, as previously observed [10]. Similar dose-dependent inhibition was also

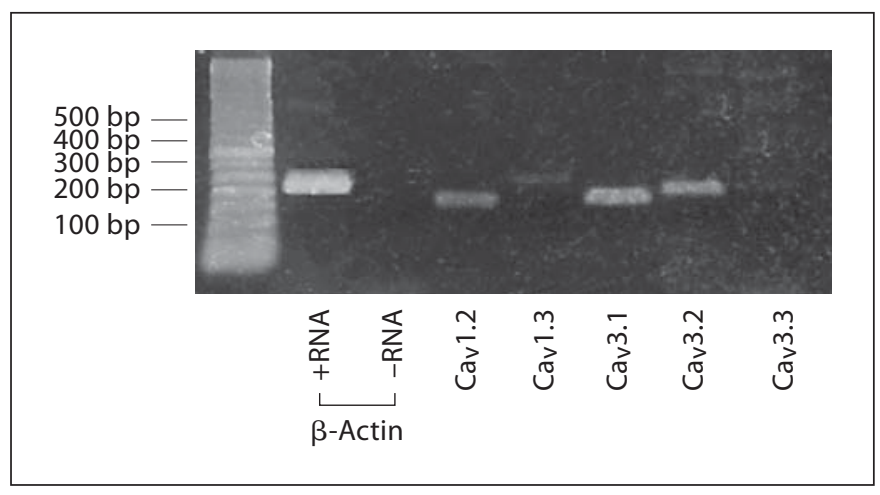

Fig. 4. Agarose gel electrophoresis showing RT-PCR products in bands corresponding to amplification of $\mathrm{Ca}^{2+}$ channel genes expressed in mesenteric terminal arterioles. Bands visible for the housekeeping gene $\beta$-actin or VDCC $\alpha_{1}$-subunits $\mathrm{Ca}_{V} 1.2$ (Ltype), $\mathrm{Ca}_{\mathrm{V}} 3.1$ (T-type) and $\mathrm{Ca}_{\mathrm{V}} 3.2$ (T-type) are of the expected sizes. At the limit of detection, a band appears at the expected product size for the $\mathrm{Ca}_{\mathrm{V}} 1.3$ (L-type) channel. No bands were detected with primer specific for the Cav3.3 (T-type) channel and in the absence of template RNA ( $\beta$-actin). Results are representative of two RT-PCR reactions on pooled RNA obtained with 67 arterioles from 5 rats.

observed for NNC 55-0396 and R(-)-efonidipine (table 2). Due to the limited solubility of $\mathrm{R}(-)$-efonidipine in PSS, this drug could not be tested at concentrations $>33 \mu \mathrm{M}$. The classical L-type blocker nifedipine (table 2) also 

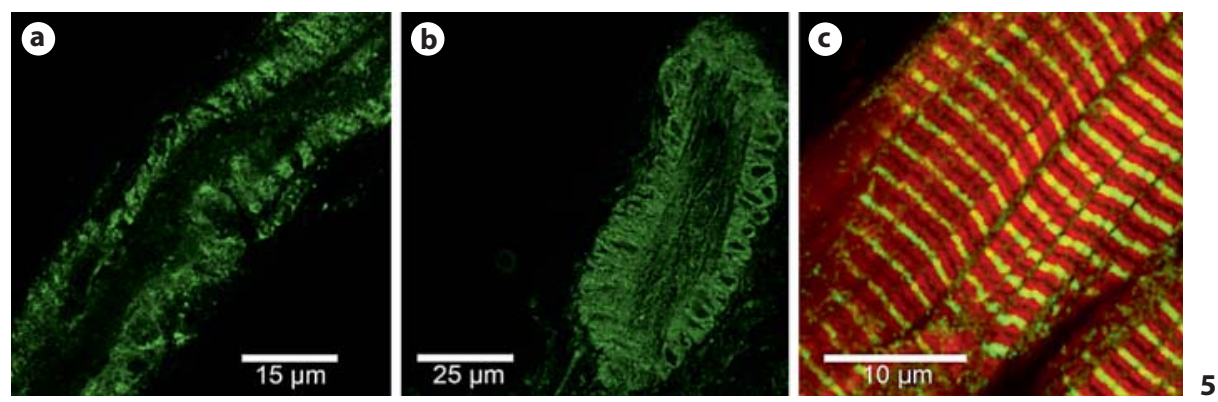

Fig. 5. Immunolocalization of $\mathrm{Ca}_{\mathrm{V}} 1.2 \mathrm{~L}$ type $\mathrm{Ca}^{2+}$ channels (green) in mesenteric terminal arterioles (a), renal afferent arterioles (b) and cardiac myocytes (c). Actin staining (red) is shown as overlay (green + red; c). To unmask the $\mathrm{Ca} \mathrm{a}_{\mathrm{V}} 1.2$ epitope, short SDS treatment was used for the mesenteric arterioles. The observed staining patterns suggest expression of L-type channels in VSMC of mesenteric and afferent arterioles, and in T-tubules of cardiac myocytes. a Representative of 3 terminal arterioles from 2 rats.

Fig. 6. Immunolocalization of $\mathrm{Ca}_{\mathrm{v}} 3.1 \mathrm{~T}$ type $\mathrm{Ca}^{2+}$ channel (green; a) in transverse section of a mesenteric arteriole. Staining of actin (red) and nuclei (blue) is included in the overlay image (b). $\mathrm{Ca}_{\mathrm{V}} 3.1$ protein is exclusively localized to VSMC with no green staining surrounding nuclei of ECs (b). $\mathrm{Ca}_{\mathrm{v}} 3.1$ localization in a longitudinal section of another mesenteric arteriole is clearly visible in the single layer of VSMC (green; c) with actin staining (red) shown as overlay (d). $\mathrm{Ca}_{\mathrm{V}} 3$.1-specific staining (green) is also shown in a small mesenteric artery (e) with multiple VSMC layers (overlay of $\mathrm{Ca}_{\mathrm{v}} 3.1$ and actin staining, $\mathbf{f}$ ). Images are representative of $\mathrm{Ca}_{\mathrm{v}} 3.1$ staining in 18 terminal arterioles and 6 small arteries from 3 rats.
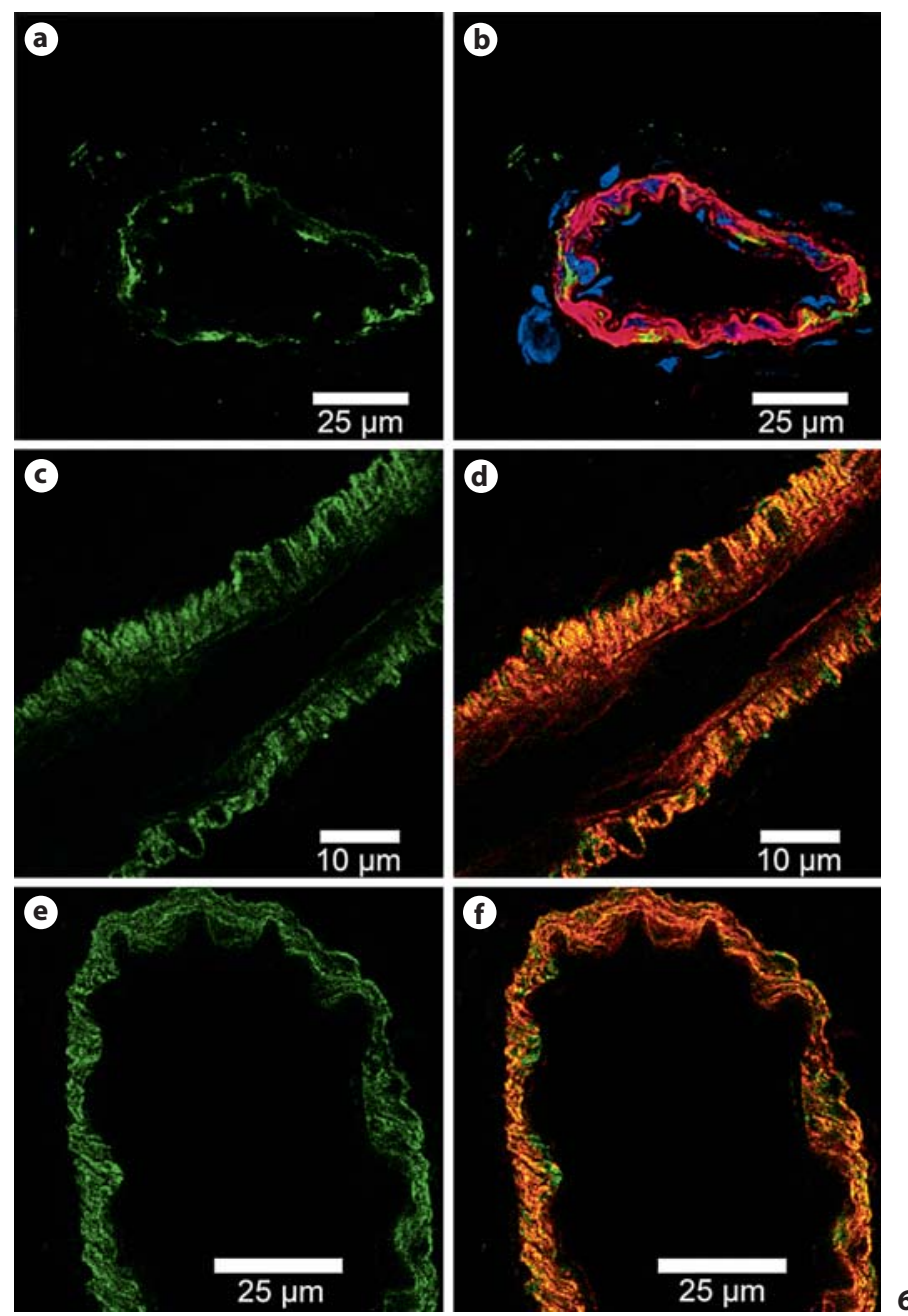

caused a reversible and concentration-dependent inhibition, but even at the high concentration of $10 \mu \mathrm{M}$, complete inhibition could not be attained, indicating the presence of a nifedipine-resistant component in KCl-induced $\mathrm{Ca}^{2+}$ entry. The concentration-response curves shown in figure 8 summarize the effects of bath-applied VDCC antagonists on the local $\mathrm{Ca}^{2+}$ responses evoked by $\mathrm{KCl}$ micro-ejection.

$\mathrm{Ca}^{2+}$ Channels and Conducted Arteriolar Responses
As the arterioles used above were non-pressurized, their cell membrane potentials might have been hyperpolarized compared to in vivo pressurized conditions. In order to re-examine the effects of VDCC blockers under depolarized conditions where classical T-type channels should be almost inactivated, we preconstricted the arterioles for $\geq 10$ min prior to $\mathrm{Ca}^{2+}$ measurements by superfusing with PSS containing $25 \mathrm{~mm} \mathrm{KCl}$. Baseline R in-

J Vasc Res 2009;46:138-151 
Fig. 7. Immunolocalization of $\mathrm{Ca}_{\mathrm{V}} 3.2$ protein is clearly visible in EC (green; a) in a longitudinal section of a mesenteric terminal arteriole. Overlay of actin and $\mathrm{Ca}_{\mathrm{v}} 3.2$ staining (red + green) is shown (b). In a close-up overlay image of an arteriolar wall (c; lumen of vessel indicated by asterisk), Cav3.2-specific staining (green) is clearly visible in an EC showing no actin staining, and scattered green staining is visible in the media $(\mathrm{M})$ identified by intense actin staining in red. A similar staining pattern was observed in a small mesenteric artery; note that EC nuclei (blue) were surrounded by green $\mathrm{Ca}_{\mathrm{v}} 3.2$-specific staining (d). Images are representative of $\mathrm{Ca}_{\mathrm{V}} 3.2$ staining in 8 arterioles and 1 small artery from 2 rats.
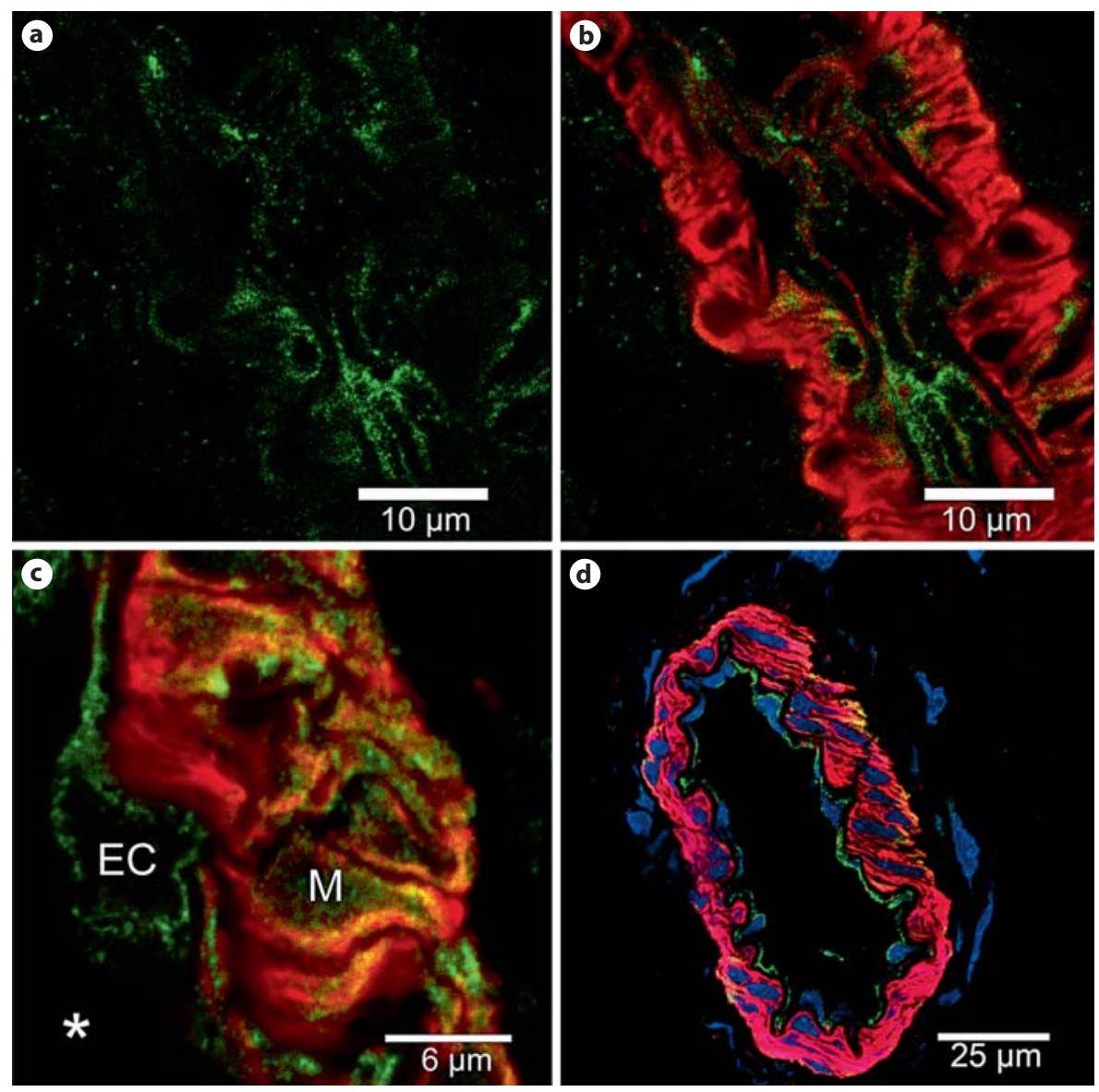

creased from $1.27 \pm 0.02$ (resting) to $1.39 \pm 0.03$ (preconstricted; $\mathrm{p}<0.01 ; \mathrm{n}=8$ ), but the local and remote $\mathrm{Ca}^{2+}$ responses evoked by $\mathrm{KCl}$ micro-ejection were not significantly different from those seen under resting conditions (table 2). NNC 55-0396 and nifedipine exerted similar effects in resting versus preconstricted arterioles with the exception of $0.1 \mu \mathrm{M}$ NNC 55-0396, which was not effective in preconstricted arterioles (fig. 8).

\section{Micro-Application of VDCC Blockers}

Finally, we questioned whether VDCCs are involved in the intercellular conduction process per se. To separate the possible effects of VDCC blockers on the local $\mathrm{Ca}^{2+}$ response from those on the conduction process, we applied either NNC 55-0396 or nifedipine (both $10 \mu \mathrm{M}$ ) by pressure micro-ejection onto the middle part of arteriolar segments (at 200-300 $\mu \mathrm{m}$ ). Both blockers severely impaired the $\mathrm{Ca}^{2+}$ responses at the site of application (300 $\mu \mathrm{m})$, but were without effect on local $(0 \mu \mathrm{m})$ and remote $(500 \mu \mathrm{m}) \mathrm{Ca}^{2+}$ responses (fig. 9).

\section{Discussion}

The results of the present study show that local $\mathrm{Ca}^{2+}$ responses evoked by local $\mathrm{KCl}$ micro-ejection were rapidly conducted to remote sites along the arteriolar wall and decayed mono-exponentially with distance. These responses were independent of neuronal $\mathrm{Na}^{+}$channels, abolished by gap junction uncouplers and disappeared in $\mathrm{Ca}^{2+}$-free solution. These observations are compatible with the notion that local $\mathrm{KCl}$ application leads to a conducted depolarization, which in turn elicits vasoconstriction via an increase in intracellular $\mathrm{Ca}^{2+}$. Conducted endothelial $\mathrm{Ca}^{2+}$ responses to local acetylcholine application were recently demonstrated in hamster feed arteries [22], and a previous study from our laboratory investigated remote $\mathrm{Ca}^{2+}$ responses in VSMCs to local current application in renal interlobular arteries [23]. The present investigation extends the latter study [23] using a different arteriolar preparation in which T-type channels have been suggested to play an important role. 
Table 2. Effect of bath application of organic VDCC blockers on local and remote $\mathrm{Ca}^{2+}$ responses

\begin{tabular}{|c|c|c|}
\hline \multirow[t]{2}{*}{$\Delta \mathrm{R} \pm \mathrm{SE}$} & \multicolumn{2}{|l|}{ Distance } \\
\hline & $0 \mu \mathrm{m}$ & $500 \mu \mathrm{m}$ \\
\hline Control $(\mathrm{n}=5 ; \mathrm{N}=3 ; \mathrm{ID}=23 \pm 4 \mu \mathrm{m})$ & $0.48 \pm 0.09$ & $0.18 \pm 0.03$ \\
\hline $0.1 \mu \mathrm{M}$ mibefradil & $0.46 \pm 0.12$ & $0.13 \pm 0.02^{*}$ \\
\hline $1.0 \mu \mathrm{M}$ mibefradil & $0.14 \pm 0.05^{*}$ & $0.02 \pm 0.006^{* * *}$ \\
\hline $10.0 \mu \mathrm{M}$ mibefradil & $-0.005 \pm 0.01^{* * *}$ & $0.00 \pm 0.00^{* * *}$ \\
\hline Control $(\mathrm{n}=5 ; \mathrm{N}=5 ; \mathrm{ID}=36 \pm 2 \mu \mathrm{m})$ & $0.35 \pm 0.05$ & $0.08 \pm 0.02$ \\
\hline $0.1 \mu \mathrm{M}$ NNC 55-0396 & $0.24 \pm 0.06^{*}$ & $0.04 \pm 0.01^{*}$ \\
\hline $1.0 \mu \mathrm{M}$ NNC 55-0396 & $0.08 \pm 0.04^{* * *}$ & $0.01 \pm 0.003^{*}$ \\
\hline $10.0 \mu \mathrm{M}$ NNC 55-0396 & $0.01 \pm 0.004^{* *}$ & $0^{* *}$ \\
\hline \multicolumn{3}{|l|}{ Resting arterioles } \\
\hline $\begin{array}{l}\text { Control }(\mathrm{n}=4 ; \mathrm{N}=2 ; \mathrm{ID}=26 \pm 4 \mu \mathrm{m}) \\
\text { Preconstricted arterioles }\end{array}$ & $0.74 \pm 0.11$ & $0.22 \pm 0.03$ \\
\hline Control $(\mathrm{n}=4 ; \mathrm{N}=2)$ & $0.68 \pm 0.11$ & $0.19 \pm 0.01$ \\
\hline $0.1 \mu \mathrm{M} N \mathrm{NNC}$ & $0.67 \pm 0.11$ & $0.21 \pm 0.02$ \\
\hline $1.0 \mu \mathrm{M} N \mathrm{NN}$ & $0.25 \pm 0.10^{*}$ & $0.05 \pm 0.01^{* * *}$ \\
\hline $10.0 \mu \mathrm{M} N \mathrm{NNC}$ & $0.00 \pm 0.00^{*}$ & $0.00 \pm 0.00^{*}$ \\
\hline Control $(\mathrm{n}=5 ; \mathrm{N}=3 ; \mathrm{ID}=16 \pm 4 \mu \mathrm{m})$ & $0.37 \pm 0.07$ & $0.15 \pm 0.04$ \\
\hline $1 \mu \mathrm{M}(\mathrm{R}-)$-efonidipine & $0.31 \pm 0.08$ & $0.12 \pm 0.03$ \\
\hline $10 \mu \mathrm{M}(\mathrm{R}-)$-efonidipine & $0.20 \pm 0.04^{*}$ & $0.08 \pm 0.02^{*}$ \\
\hline $33 \mu \mathrm{M}(\mathrm{R}-)$-efonidipine & $0.15 \pm 0.03^{*}$ & $0.05 \pm 0.01^{*}$ \\
\hline Control $(\mathrm{n}=5 ; \mathrm{N}=4 ; \mathrm{ID}=25 \pm 4 \mu \mathrm{m})$ & $0.44 \pm 0.06$ & $0.13 \pm 0.02$ \\
\hline $0.1 \mu \mathrm{M}$ nifedipine & $0.30 \pm 0.05^{*}$ & $0.05 \pm 0.01^{* *}$ \\
\hline $1.0 \mu \mathrm{M}$ nifedipine & $0.10 \pm 0.03^{* *}$ & $0.02 \pm 0.01^{* *}$ \\
\hline $10.0 \mu \mathrm{M}$ nifedipine & $0.07 \pm 0.03^{* *}$ & $0.01 \pm 0.005^{* *}$ \\
\hline \multicolumn{3}{|l|}{ Resting arterioles } \\
\hline $\begin{array}{l}\text { Control }(\mathrm{n}=4 ; \mathrm{N}=2 ; \mathrm{ID}=25 \pm 4 \mu \mathrm{m}) \\
\text { Preconstricted arterioles }\end{array}$ & $0.90 \pm 0.14$ & $0.25 \pm 0.03$ \\
\hline Control $(n=4 ; N=2)$ & $0.54 \pm 0.12$ & $0.25 \pm 0.06$ \\
\hline $0.1 \mu \mathrm{M}$ nifedipine & $0.40 \pm 0.15$ & $0.09 \pm 0.03$ \\
\hline $1.0 \mu \mathrm{M}$ nifedipine & $0.17 \pm 0.07^{*}$ & $0.01 \pm 0.008^{*}$ \\
\hline $10.0 \mu \mathrm{M}$ nifedipine & $0.09 \pm 0.04^{*}$ & $0.01 \pm 0.003^{*}$ \\
\hline
\end{tabular}

${ }^{*} \mathrm{p}<0.05,{ }^{* *} \mathrm{p}<0.01,{ }^{* *} \mathrm{p}<0.001$, drug vs. control.

The key findings with respect to the involvement of Ttype channels in local and remote $\mathrm{Ca}^{2+}$ responses are: (1) T-type channels do not mediate the conduction of depolarizing signals per se, but contribute to local electromechanical coupling via $\mathrm{Ca}^{2+}$ entry. Furthermore, our immunohistochemical as well as functional data show that: (2) two isoforms of T-type VDCCs, $\mathrm{Ca}_{\mathrm{y}} 3.1$ and $\mathrm{Ca}_{\mathrm{V}} 3.2$, are expressed at the protein level in vascular smooth muscle and/or endothelium of rat mesenteric arterioles. (3) In addition to the L-type VDCC blocker nifedipine, NNC 55-0396 and (R-)-efonidipine, two Ttype VDCC-specific blockers, also effectively block depolarization-induced $\mathrm{Ca}^{2+}$ entry in rat mesenteric terminal arterioles.

$\mathrm{Ca}^{2+}$ Channels and Conducted Arteriolar Responses
Although loading of Fura into VSMCs of intact arterioles was achieved by abluminal exposure to the dye, it cannot be excluded that some loading of ECs will take place. However, the loaded cells showed up as brightly fluorescent bands oriented perpendicular to the length axis of the vessel, and the images were obtained by focusing on the media of the vessel. Finally, there was a strict correlation between increases in the $\left[\mathrm{Ca}^{2+}\right]$ signal and vasoconstriction (fig. 2a). It is therefore highly likely that the recorded fluorescence predominantly originated from VSMCs. The estimated resting $\left[\mathrm{Ca}^{2+}\right]_{\mathrm{i}}$ of $\sim 100 \mathrm{nM}$ in our study compare well with previously reported estimates $(70-110 \mathrm{nM})$ in non-pressurized arterioles [10, 24]. However, estimates from pressurized arterioles are slightly higher (130-170 nM), most likely due to pressure-induced depolarization of VSMC $[25,26]$.

\section{Role of Intercellular Communication}

The remote $\mathrm{Ca}^{2+}$ responses were inhibited by the gap junction uncouplers carbenoxolone and palmitoleic acid, with no significant effects on local $\mathrm{Ca}^{2+}$ responses (fig. 3). In previous studies, both palmitoleic acid and carbenoxolone were shown to inhibit gap junctional communication in a concentration-dependent manner without extra-junctional effects at the concentrations used in the present study [17, 27-29]. The role of gap junctions for conducted vasomotor responses was originally proposed by Segal et al. [2] and Segal and Duling [5] based on studies performed in hamster cheek pouch arterioles. During the last 2 decades, a large body of evidence has confirmed the central role of gap junctions for conducted vasomotor responses [for a recent review, see ref. 1]. The cellular pathway for the conducted response to $\mathrm{KCl}$ was not resolved in the present study. However, connexins 37, 40 and 43 were previously shown to be expressed exclusively in the endothelium of rat mesenteric arterioles [6]. Whether the local depolarization was conducted via the endothelium or smooth muscle is not critical for the conclusions of the present study.

\section{Role of VDCCs}

Voltage-dependent L-type $\mathrm{Ca}^{2+}$ channels provide a crucial link between excitation and contraction in vascular smooth muscle. Recently, additional roles of Ttype and P/Q-type channels in excitation-contraction coupling have been demonstrated in renal resistance vessels [30, 31]. In rat mesenteric small arteries and arterioles, our previous investigations have suggested the presence of T-type channels and the absence of N-, P/Qand R-type channels [9-11]. Our RT-PCR results (fig. 4) 


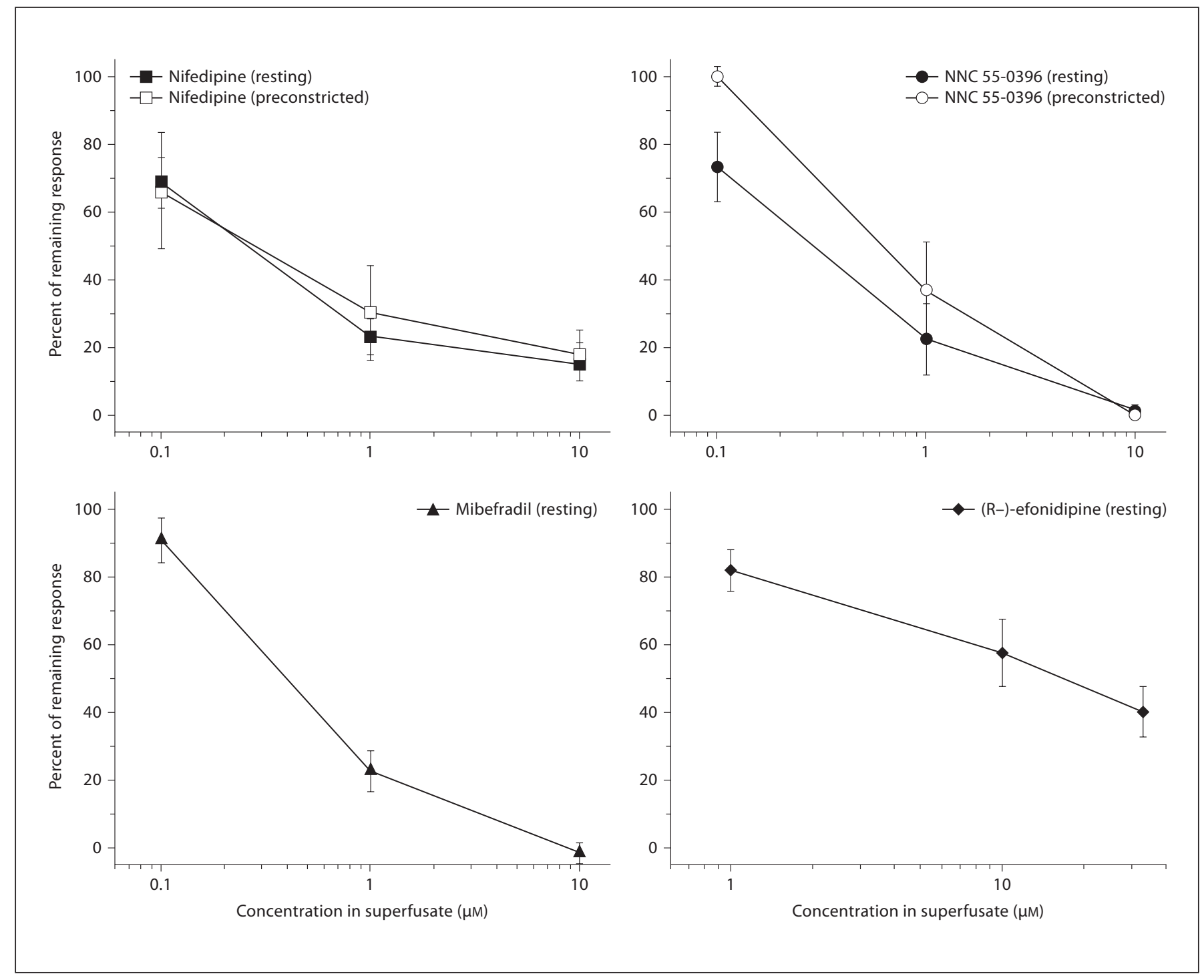

Fig. 8. Concentration-response curves for the effects of nifedipine $(\mathrm{n}=5 ; \mathrm{N}=4)$ and the T-type blockers mibefradil $(\mathrm{n}=5 ; \mathrm{N}=3)$, NNC 55-0396 $(\mathrm{n}=5 ; \mathrm{N}=4)$ and $\mathrm{R}(-)$-efonidipine $(\mathrm{n}=5 ; \mathrm{N}=3)$ on local $\mathrm{Ca}^{2+}$ responses to local $\mathrm{KCl}$ application in arterioles maintained under control ('resting') or depolarized ('preconstricted') conditions. See table 2 for corresponding $\Delta \mathrm{R}$ data. indicated that one L-type isoform $\left(\mathrm{Ca}_{\mathrm{V}} 1.2\right)$ and two Ttype isofoms $\left(\mathrm{Ca}_{\mathrm{V}} 3.1\right.$ and $\left.\mathrm{Ca}_{\mathrm{V}} 3.2\right)$ were expressed in rat mesenteric arterioles. Furthermore, L- and T-type proteins $\left(\mathrm{Ca}_{\mathrm{V}} 1.2, \mathrm{Ca}_{\mathrm{V}} 3.1\right.$ and $\left.\mathrm{Ca}_{\mathrm{V}} 3.2\right)$ were localized in VSMCs, and $\mathrm{Ca}_{\mathrm{V}} 3.2$ was also clearly present in ECs (fig. 5-7). To our knowledge, these results are the first direct demonstration of endothelial expression of $\mathrm{Ca}_{V} 3.2$ in arterial tissues.

Our previous investigations showed that L-type channels were not expressed in rat mesenteric arterioles $[9,10]$. However, in those studies, we used terminal arterioles
(ID $\sim 15 \mu \mathrm{m}$ ) isolated from the transparent mesenteric connective tissue, whereas in the present study we used terminal arterioles (ID $\sim 24 \mu \mathrm{m}$ ) from the fat pad adjacent to the ileum. Whether such regional differences may explain this discrepancy is unknown, but it is possible that the expression of L-type channels gradually disappears and conversely the expression of T-type channels predominates in the smallest and most peripheral branches of the rat mesenteric arteriolar tree, as reported previously for the guinea pig [32]. 


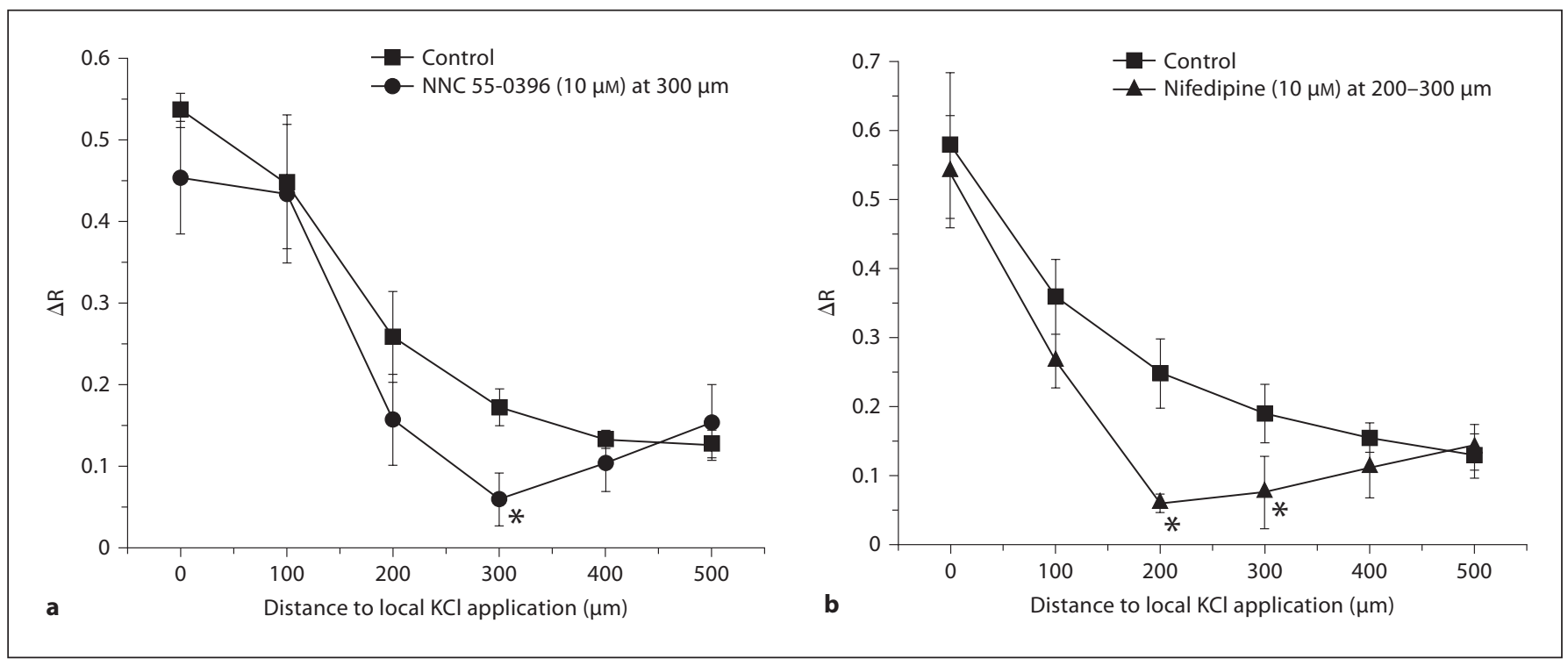

Fig. 9. a Summary of results obtained for micropipette delivery of the T-type blocker NNC 55-0396 $(10 \mu \mathrm{M})$ to a narrow region of the arteriole at $\sim 300 \mu \mathrm{m}$ from the site of local $\mathrm{KCl}$ application $\left({ }^{*} \mathrm{p}<0.05 ; \mathrm{n}=5 ; \mathrm{N}=4 ; \mathrm{ID}=23 \pm 3 \mu \mathrm{m}\right)$. b Summary of results

obtained for micropipette delivery of nifedipine $(10 \mu \mathrm{M})$ at $200-$ $300 \mu \mathrm{m}$ from the site of local $\mathrm{KCl}$ application $\left({ }^{*} \mathrm{p}<0.05 ; \mathrm{n}=4\right.$; $\mathrm{N}=4 ; \mathrm{ID}=21 \pm 3 \mu \mathrm{m})$

The antibodies used in the present study were specific for the respective $\mathrm{Ca}^{2+}$ channel epitopes. The $\mathrm{Ca}_{\mathrm{V}} 1.2$ antibody produced positive control staining in both renal afferent arterioles and cardiac myocytes, two types of native tissue known to abundantly express L-type channels. The Cav 3.1 antibody, which generated highly reproducible results in mesenteric arterioles, is well characterized in brain tissue where the channel localization is consistent with that revealed by in situ hybridization [13]. In the same study, this antibody detected $\mathrm{Ca}_{\mathrm{V}} 3.1$ expression in rat aorta and coronary artery, and in peripheral vasculature in rat brain, kidney, lung, liver and testes [13]. The $\mathrm{Ca}_{\mathrm{V}} 3.2$ antibody specifically recognizes a protein with the expected molecular weight in a $\mathrm{Ca}_{\mathrm{V}} 3.2$-expressing cell line (manufacturer's product information), and incubation with the epitopic peptide eliminated the staining in rat mesenteric arterioles (present study). The observed endothelial localization of $\mathrm{Ca}_{\mathrm{v}} 3.2$-specific staining is not consistent with a role in vasoconstriction. Interestingly, a recent report has postulated a role for $\mathrm{Ca}_{\mathrm{V}} 3.2$ channels in conducted vasodilatation to local electrical stimulation in mouse cremaster arterioles [33], and it has been shown that genetic elimination of $\mathrm{Ca}_{\mathrm{V}} 3.2$ results in marked attenuation of endothelial- and NO-dependent vasodilatation in coronary arteries [34]. T-type channels are also suggested to participate in differentiation and prolifera-

tion [35] as well as control of von Willebrand factor secretion and coagulation in lung microvascular endothelium [36].

Mibefradil has previously been used as a selective blocker of T-type channels at $\leq 1 \mu \mathrm{M}$ [18]. However, its antihypertensive effects were recently shown to be mediated via the block of $\mathrm{Ca}_{V} 1.2 \mathrm{~L}$-type channels [37]. Instead we have used NNC 55-0396 and R(-)-efonidipine, two new organic T-type blockers. NNC 55-0396 is a new nonhydrolyzable analogue of mibefradil, which is not metabolized in the cytoplasm to an active form responsible for block of L-type channels [19]. NNC 55-0396 did not block high voltage-activated currents in insulin-secreting INS-1 cells at a high concentration $(100 \mu \mathrm{M})$, whereas it blocked $\mathrm{Ca}_{\mathrm{V}} 3.1$ T-type currents expressed in HEK293 cells with an $\mathrm{IC}_{50}$ of $\sim 7 \mu \mathrm{M}$ [19]. Thus, the fact that $10 \mu \mathrm{M}$ NNC 55-0396 abolished the local and remote $\mathrm{Ca}^{2+}$ responses indicates that T-type channels are functionally important in mesenteric terminal arterioles. At $1 \mu \mathrm{M}$, NNC 55-0396 blocked both local and remote $\mathrm{Ca}^{2+}$ responses by $>50 \%$, which indicates a higher efficacy than that reported for inhibition of Cav3.1 T-type currents [19]. This may be caused by a different drug sensitivity of native T-type channels expressed in mesenteric arterioles. The $\mathrm{R}(-)$-enantiomer of efonidipine inhibited $\mathrm{T}$ type currents in mammalian cells or amphibian oocytes 
with $\mathrm{IC}_{50}$ values ranging from 0.1 to $10 \mu \mathrm{M}$, with little or no effect on high voltage-activated currents [20, 21]. Although we were not able to estimate the maximum effect of R(-)-efonidipine, its concentration-dependent effects in mesenteric arterioles are consistent with a role for $\mathrm{T}$ type channels.

Nifedipine is a potent L-type blocker with an $\mathrm{IC}_{50}$ of $3.7 \cdot 10^{-9} \mathrm{M}$ for voltage-dependent block $\left(\mathrm{V}_{\mathrm{H}}=-50 \mathrm{mV}\right)$ of the vascular isoform of $\mathrm{Ca}_{V} 1.2\left(\alpha_{1 \mathrm{C}-\mathrm{b}}\right)$ [38]. In the present study, a much higher concentration of nifedipine $(0.1-1 \mu \mathrm{M})$ was required to block $50 \%$ of the $\mathrm{KCl}-$ induced $\mathrm{Ca}^{2+}$ responses (fig. 8). Nimodipine has long been recognized as a partial blocker of T-type channels $[32,39]$, and it has been reported that nifedipine blocks both native and recombinant T-type currents, with the highest sensitivity $\left(\mathrm{IC}_{50}=1.2-5 \mu \mathrm{M}\right)$ displayed by currents carried via Cav 3.2 channels $[40,41]$. Thus, the moderate efficacy obtained with nifedipine in mesenteric terminal arterioles may suggest that its effects are due to a predominant expression of T-type channels in this preparation.

To test if the potent effect of NNC 55-0396 could be attributed to the hyperpolarized membrane potential of isolated, non-pressurized arterioles, we performed another set of experiments in which the arterioles were partially depolarized and preconstricted using PSS containing $25 \mathrm{mM} \mathrm{KCl}$ (fig. 8). Under these conditions, the membrane potential should be sufficiently depolarized $\left(\mathrm{E}_{\mathrm{K}} \sim\right.$ $-45 \mathrm{mV}$ ) to inactivate classical T-type channels [42]. The results, however, indicated that, except for a very low concentration $(0.1 \mu \mathrm{M})$, the potency of NNC 55-0396 (1$10 \mu \mathrm{M})$ remained almost unchanged (fig. 8). This result may indicate unusually high activation and inactivation thresholds of T-type channels expressed in mesenteric terminal arterioles, as previously reported for mesenteric small arteries [11, 32].

The potent effects of either nifedipine or NNC 550396 on the $\mathrm{Ca}^{2+}$ responses in mesenteric terminal arterioles deserve attention. These results are not compatible with an additive effect of NNC 55-0396 and nifedipine, and may suggest a functional coupling between L- and T-type channels. A functional coupling might be the consequence of a co-localization and interaction between Land T-type channels in membrane microdomains, such as caveolae. Such non-additive effects of L- and T-type blockers have previously been observed in preglomerular resistance arterioles [31].

The finding that inhibition of $\mathrm{Ca}^{2+}$ entry by micro-application of nifedipine or NNC 55-0396 between the local and the remote sites did not affect local and remote $\mathrm{Ca}^{2+}$ responses (fig. 9) suggests that the (inward) $\mathrm{Ca}^{2+}$ currents through VDCCs do not contribute to the conducted depolarization initiated by local $\mathrm{KCl}$ application. If this was the case, we would have expected the $\mathrm{Ca}^{2+}$ response at the most remote site $(500 \mu \mathrm{m})$ to be diminished by blocking $\mathrm{Ca}^{2+}$ entry at a site half-way along the arteriolar preparation. Thus, the role of VDCCs seems to be limited to providing local electromechanical coupling rather than supporting conduction during a locally initiated vasomotor response.

In summary, we have shown that local application of a depolarizing $\mathrm{KCl}$ solution leads to local and remote $\mathrm{Ca}^{2+}$ responses in terminal arterioles isolated from the rat mesenteric fat pad. The conduction mechanism most likely involves intercellular electrical communication via gap junctions, as remote $\mathrm{Ca}^{2+}$ responses were inhibited by two chemically distinct gap junction uncouplers. We detected mRNA and protein expression of $\mathrm{Ca}_{\mathrm{V}} 1.2, \mathrm{Ca}_{\mathrm{V}} 3.1$ and $\mathrm{Ca}_{\mathrm{V}} 3.2$ VDCCs, and we provided evidence that both $\mathrm{L}$ - and T-type VDCCs are involved in electromechanical coupling, but are not necessary for the conduction of vasoconstrictor signals per se.

\section{Acknowledgments}

Financial support from the Japan Society for the Promotion of Science, the Danish Medical Research Council, the Danish Heart Association, the Novo Nordisk Foundation and the Lundbeck Foundation is gratefully acknowledged. L.J.J. was a post-doctoral fellow at the Kyushu University during part of the study. R(-)efonidipine was a kind gift from Nissan Chemical Industries, Tokyo, Japan.

References 
6 Gustafsson F, Mikkelsen HB, Arensbak B, Thuneberg L, Neve S, Jensen LJ, HolsteinRathlou NH: Expression of connexin 37, 40 and 43 in rat mesenteric arterioles and resistance arteries. Histochem Cell Biol 2003;119: 139-148.

7 Xia J, Duling BR: Electromechanical coupling and the conducted vasomotor response. Am J Physiol 1995;269:H2022-H2030.

8 Welsh DG, Segal SS: Endothelial and smooth muscle cell conduction in arterioles controlling blood flow. Am J Physiol 1998;274: H178-H186.

-9 Gustafsson F, Andreasen D, Salomonsson M, Jensen BL, Holstein-Rathlou N: Conducted vasoconstriction in rat mesenteric arterioles: role for dihydropyridine-insensitive $\mathrm{Ca}^{2+}$ channels. Am J Physiol Heart Circ Physiol 2001;280:H582-H590.

10 Jensen LJ, Salomonsson M, Jensen BL, Holstein-Rathlou NH: Depolarization-induced calcium influx in rat mesenteric small arterioles is mediated exclusively via mibefradilsensitive calcium channels. Br J Pharmacol 2004;142:709-718.

11 Morita H, Shi J, Ito Y, Inoue R: T-channellike pharmacological properties of high voltage-activated, nifedipine-insensitive $\mathrm{Ca}^{2+}$ currents in the rat terminal mesenteric artery. Br J Pharmacol 2002;137:467-476.

12 Vorndran C, Minta A, Poenie M: New fluorescent calcium indicators designed for cytosolic retention or measuring calcium near membranes. Biophys J 1995;69:2112-2124.

13 Brueggemann LI, Martin BL, Barakat J, Byron KL, Cribbs LL: Low voltage-activated calcium channels in vascular smooth muscle: T-type channels and AVP-stimulated calcium spiking. Am J Physiol Heart Circ Physiol 2005;288:H923-H935.

14 Jensen LJ, Stuart-Tilley AK, Peters LL, Lux SE, Alper SL, Breton S: Immunolocalization of AE2 anion exchanger in rat and mouse epididymis. Biol Reprod 1999;61:973-980.

-15 Kenny LC, Baker PN, Kendall DA, Randall MD, Dunn WR: The role of gap junctions in mediating endothelium-dependent responses to bradykinin in myometrial small arteries isolated from pregnant women. Br J Pharmacol 2002;136:1085-1088.

16 Lamboley M, Pittet P, Koenigsberger M, Sauser R, Beny JL, Meister JJ: Evidence for signaling via gap junctions from smooth muscle to endothelial cells in rat mesenteric arteries: possible implication of a second messenger. Cell Calcium 2005;37:311-320.

-17 Fanchaouy M, Serir K, Meister JJ, Beny JL, Bychkov R: Intercellular communication: role of gap junctions in establishing the pattern of ATP-elicited $\mathrm{Ca}^{2+}$ oscillations and $\mathrm{Ca}^{2+}$-dependent currents in freshly isolated aortic smooth muscle cells. Cell Calcium 2005;37:25-34.
8 Mishra SK, Hermsmeyer K: Selective inhibition of T-type $\mathrm{Ca}^{2+}$ channels by Ro 40-5967. Circ Res 1994;75:144-148.

19 Huang L, Keyser BM, Tagmose TM, Hansen JB, Taylor JT, Zhuang H, Zhang M, Ragsdale DS, Li M: NNC 55-0396 [(1S,2S)-2-(2-(N[(3-benzimidazol-2-yl)propyl]-N-methylamino)ethyl)-6-fluoro-1,2,3,4-tetrahydro-1-isopropyl-2-naphtyl cyclopropanecarboxylate dihydrochloride]: a new selective inhibitor of T-type calcium channels. J Pharmacol Exp Ther 2004;309:193-199.

20 Furukawa T, Miura R, Honda M, Kamiya N, Mori Y, Takeshita S, Isshiki T, Nukada T: Identification of R(-)-isomer of efonidipine as a selective blocker of T-type $\mathrm{Ca}^{2+}$ channels. Br J Pharmacol 2004;143:1050-1057.

-21 Tanaka H, Komikado C, Shimada H, Takeda K, Namekata I, Kawanishi T, Shigenobu K: The R(-)-enantiomer of efonidipine blocks T-type but not L-type calcium current in guinea pig ventricular myocardium. J Pharmacol Sci 2004;96:499-501.

22 Uhrenholt TR, Domeier TL, Segal SS: Propagation of calcium waves along endothelium of hamster feed arteries. Am J Physiol Heart Circ Physiol 2007;292:H1634-H1640.

-23 Salomonsson M, Gustafsson F, Andreasen D, Jensen BL, Holstein-Rathlou NH: Local electric stimulation causes conducted calcium response in rat interlobular arteries. Am J Physiol Renal Physiol 2002;283:F473F480.

24 Salomonsson M, Arendshorst WJ: Calcium recruitment in renal vasculature: $\mathrm{NE}$ effects on blood flow and cytosolic calcium concentration. Am J Physiol 1999;276:F700-F710.

25 Yashiro Y, Duling BR: Integrated $\mathrm{Ca}^{2+}$ signaling between smooth muscle and endothelium of resistance vessels. Circ Res 2000;87: 1048-1054.

26 Zou H, Ratz PH, Hill MA: Role of myosin phosphorylation and $\left[\mathrm{Ca}^{2+}\right]_{\mathrm{i}}$ in myogenic reactivity and arteriolar tone. Am J Physiol 1995;269:H1590-H1596.

-27 Palani D, Ghildyal P, Manchanda R: Effects of carbenoxolone on syncytial electrical properties and junction potentials of guineapig vas deferens. Naunyn Schmiedebergs Arch Pharmacol 2006;374:207-214

28 Schuster A, Oishi H, Beny JL, Stergiopulos N, Meister JJ: Simultaneous arterial calcium dynamics and diameter measurements: ap plication to myoendothelial communication. Am J Physiol Heart Circ Physiol 2001; 280:H1088-H1096.

29 Dhein S, Krusemann K, Schaefer T: Effects of the gap junction uncoupler palmitoleic acid on the activation and repolarization wavefronts in isolated rabbit hearts. Br J Pharmacol 1999;128:1375-1384.

-30 Hansen PB, Jensen BL, Andreasen D, Friis UG, Skott O: Vascular smooth muscle cells express the $\alpha_{1 \mathrm{~A}}$ subunit of a P-/Q-type voltage-dependent $\mathrm{Ca}^{2+}$ channel, and it is functionally important in renal afferent arterioles. Circ Res 2000;87:896-902.
31 Hansen PB, Jensen BL, Andreasen D, Skott O: Differential expression of T- and L-type voltage-dependent calcium channels in renal resistance vessels. Circ Res 2001;89:630638.

32 Morita H, Cousins H, Onoue H, Ito Y, Inoue $\mathrm{R}$ : Predominant distribution of nifedipineinsensitive, high voltage-activated $\mathrm{Ca}^{2+}$ channels in the terminal mesenteric artery of guinea pig. Circ Res 1999;85:596-605.

33 Figueroa XF, Chen CC, Campbell KP, Damon DN, Day KH, Ramos S, Duling BR: Are voltage-dependent ion channels involved in the endothelial cell control of vasomotor tone? Am J Physiol Heart Circ Physiol 2007; 293:H1371-H1383.

>34 Chen CC, Lamping KG, Nuno DW, Barresi R, Prouty SJ, Lavoie JL, Cribbs LL, England SK, Sigmund CD, Weiss RM, Williamson RA, Hill JA, Campbell KP: Abnormal coronary function in mice deficient in $\alpha_{1 \mathrm{H}}$ T-type $\mathrm{Ca}^{2+}$ channels. Science 2003;302:1416-1418.

$\checkmark 35$ Lory P, Bidaud I, Chemin J: T-type calcium channels in differentiation and proliferation. Cell Calcium 2006;40:135-146.

$>36$ Zhou C, Chen H, Lu F, Sellak H, Daigle JA, Alexeyev MF, Xi Y, Ju J, van Mourik JA, Wu S: $\mathrm{Ca}_{\mathrm{v}} 3.1\left(\alpha_{1 \mathrm{G}}\right)$ controls von Willebrand factor secretion in rat pulmonary microvascular endothelial cells. Am J Physiol Lung Cell Mol Physiol 2007;292:L833-L844.

37 Moosmang S, Haider N, Bruderl B, Welling A, Hofmann F: Antihypertensive effects of the putative T-type calcium channel antagonist mibefradil are mediated by the L-type calcium channel $\mathrm{Ca}_{\mathrm{v}} 1.2$. Circ Res 2006;98: 105-110.

38 Morel N, Buryi V, Feron O, Gomez JP, Christen MO, Godfraind T: The action of calcium channel blockers on recombinant L-type calcium channel $\alpha_{1}$-subunits. Br J Pharmacol 1998;125:1005-1012.

$>39$ Randall AD, Tsien RW: Contrasting biophysical and pharmacological properties of T-type and R-type calcium channels. Neuropharmacology 1997;36:879-893.

40 Lee TS, Kaku T, Takebayashi S, Uchino T, Miyamoto S, Hadama T, Perez-Reyes E, Ono $\mathrm{K}$ : Actions of mibefradil, efonidipine and nifedipine block of recombinant T- and Ltype Ca channels with distinct inhibitory mechanisms. Pharmacology 2006;78:11-20.

41 Shcheglovitov A, Zhelay T, Vitko Y, Osipenko V, Perez-Reyes E, Kostyuk P, Shuba Y: Contrasting the effects of nifedipine on subtypes of endogenous and recombinant $\mathrm{T}$ type $\mathrm{Ca}^{2+}$ channels. Biochem Pharmacol 2005;69:841-854.

42 Perez-Reyes E: Molecular physiology of lowvoltage-activated T-type calcium channels. Physiol Rev 2003;83:117-161. 